\title{
A STUDY ON NEUROCUTANEOUS SYNDROMES IN A RURAL TEACHING INSTITUTE- A SOUTH INDIAN STUDY
}

Siddarth Amuthan 1 , Chidambaranathan Sivaprakasam², Logesvar Palanisamy³

${ }^{1}$ Student, Rajah Muthiah Medical College.

${ }^{2}$ Associate Professor, Department of Paediatrics, Rajah Muthiah Medical College.

${ }^{3}$ Student, Rajah Muthiah Medical College.

\section{ABSTRACT}

\section{BACKGROUND}

Neurocutaneous syndromes are a group of central nervous system diseases that manifests with a specific skin lesion. The association between the lesion and the disease is so high that it can be encountered before its neurological sequelae. The sequelae persist throughout the life.

The objective of this study is to find the incidence of neurocutaneous syndrome in paediatric practice.

\section{MATERIALS AND METHODS}

Head foot inspection of skin for the known neurocutaneous markers prospectively on all patients below the age of 12 years for six months during September 2016 to February 2017. The disease is confirmed by the radiological findings or based on the diagnostic criteria specific for that condition. Statistical analysis of the demographic details and the disease was done.

\section{RESULTS}

Seven cases of neurocutaneous syndromes were detected among 13,069 patients screened by head to foot inspection of the skin. On average per 1,000 children aged less than twelve years is 5.35 children who were diagnosed with neurocutaneous syndromes. The results are statistically significant.

\section{KEYWORDS}

Neurocutaneous Syndromes, Incidence, Markers, Neurological Sequelae.

HOW TO CITE THIS ARTICLE: Amuthan S, Sivaprakasam C, Palanisamy L. A study on neurocutaneous syndromes in a rural teaching institute- a South Indian study. J. Evolution Med. Dent. Sci. 2017;6(33):2769-2771, DOI: 10.14260/Jemds/2017/596

\section{BACKGROUND}

Neurocutaneous syndromes are a group of central nervous system diseases that manifests with a specific skin lesion.[1] The association between the lesion and the disease is so high that it can be encountered before its neurological sequelae. The sequelae persist throughout the life. Sturge-Weber, Tuberous sclerosis complex and Sjogren-Larsson syndromes, neurofibromatosis, Von Hippel-Lindau syndrome, melanosis of Ito, are very rare forms of neurocutaneous diseases seen in clinical practice.[2] Sturge-Weber syndrome is one of the often associated with port-wine stains of the face, glaucoma, seizures, mental retardation and ipsilateral leptomeningeal angioma.[3] It of three types, type-I presents with facial and leptomeningeal angioma as well as possibility of glaucoma and coloboma, type-II appears with facial angioma, glaucoma with any brain involvement and type-III has features of leptomeningeal angioma.[4] Port-wine stain is removed by laser, anticonvulsant and anti-glaucoma medications with supportive therapy for other symptoms. Tuberous Sclerosis Complex (TSC) is a genetic disorder with an autosomal dominant pattern of inheritance, variable expressivity and complete penetrance. Sherlock coined the term Epiloia

Financial or Other, Competing Interest: None.

Submission 10-03-2017, Peer Review 08-04-2017,

Acceptance 15-04-2017, Published 24-04-2017.

Corresponding Author:

Siddarth Amuthan,

37 - H South Marret Street

Victory House,

Madurai-625001.

E-mail: amuthansiddarth@gmail.com

DOI: $10.14260 /$ jemds $/ 2017 / 596$ encompassing the clinical triad of tuberous sclerosis (Epi: epilepsy, Loi: low intelligence, A: adenoma sebaceum. ${ }^{[5]}$ No pathognomonic clinical signs for TSC complex are seen. TSC is caused by a mutation of either of two genes, TSC1 and TSC2, which code for the proteins hamartin and tuberin, respectively. These proteins act as tumour growth suppressors, agents that regulate cell proliferation and differentiation. ${ }^{[6]}$ TSC affects tissues from different germ layers. Sjögren-Larsson syndrome is an autosomal recessive disease with a triad of ichthyosis at birth, spastic paraplegia and intellectual delay. It is associated with deficiency of fatty aldehyde dehydrogenase. ${ }^{[7]}$

\section{Objective}

- To identify the known neurocutaneous markers and correlate with the imaging findings.

- To find the incidence of neurocutaneous syndromes among children less than twelve years.

\section{MATERIALS AND METHODS}

The study is conducted in the paediatric outpatient facility in a rural institute in South India. It is conducted from August 2016 to January 2017. During the six months of study, all the outpatients aged less than twelve years were screened with head to foot examination for neurocutaneous markers. Patient with haemangioma in the torso and limbs were excluded from the study. All the patients with the markers were subjected to appropriate imaging studies for confirmation. 


\section{RESULTS}

Among the 13,069 patients with neurocutaneous markers, seven cases of neurocutaneous syndromes were detected and confirmed using radiological features. Most of them presented due to other complaints. On average per 1,000 children aged less than twelve years, 5.35 children were diagnosed with neurocutaneous syndromes (Table 1).

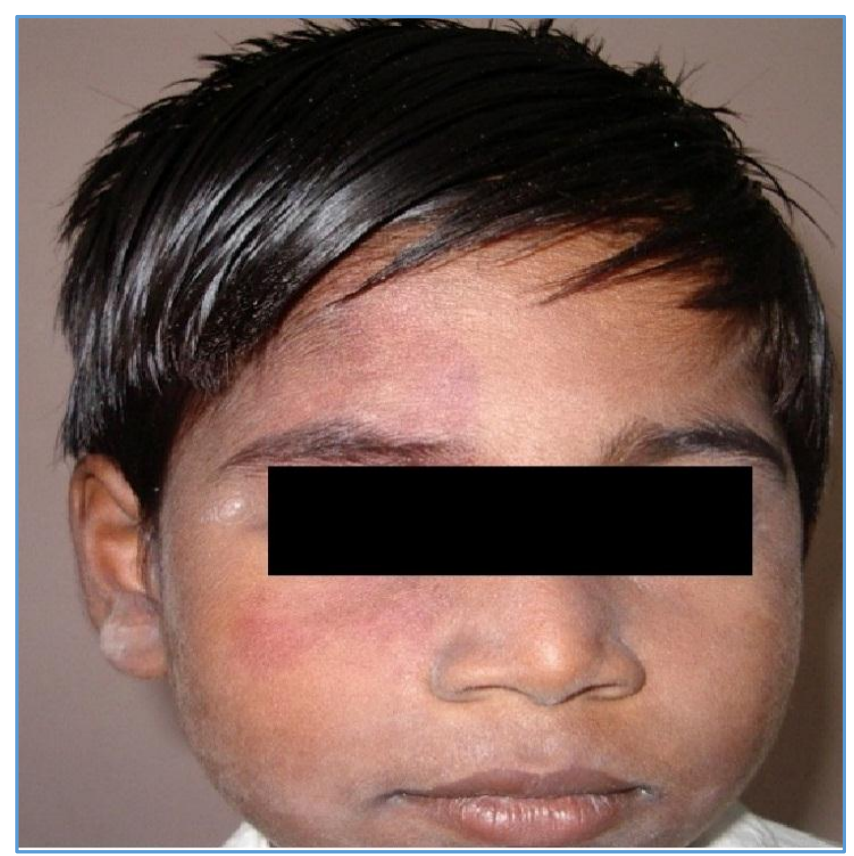

Figure 1. Port-Wine Stain

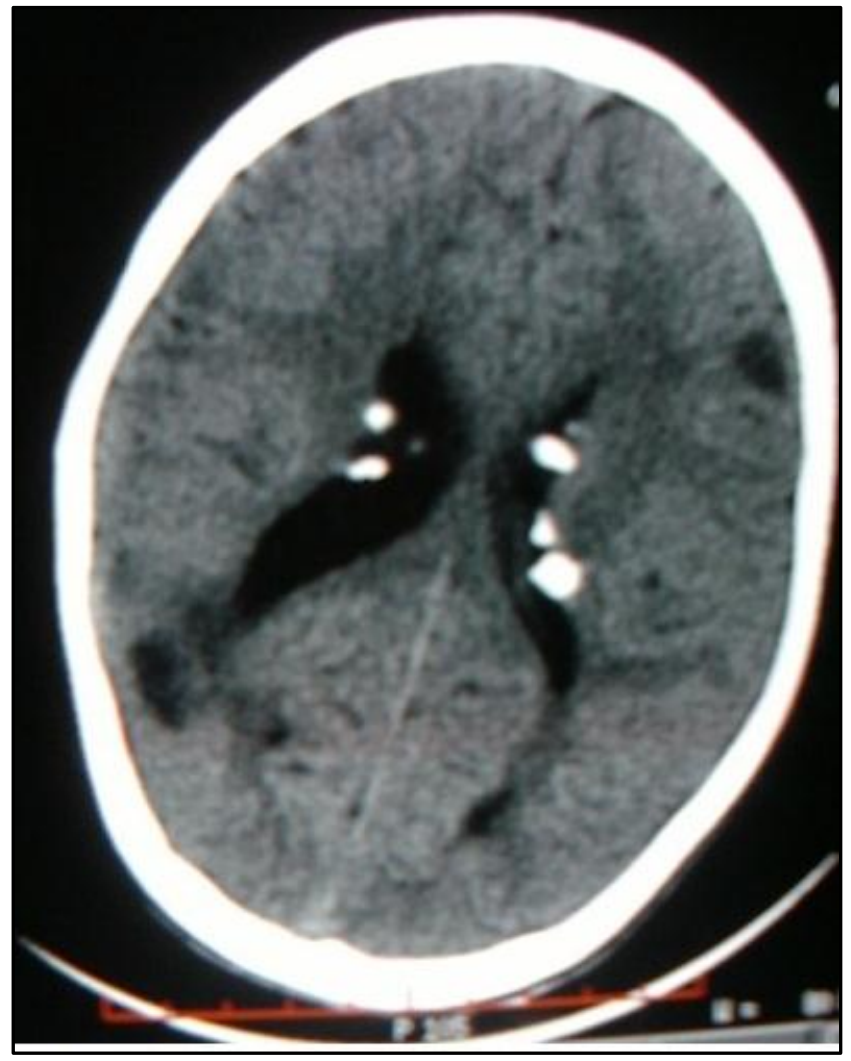

Figure 2. Subependymal Calcifications

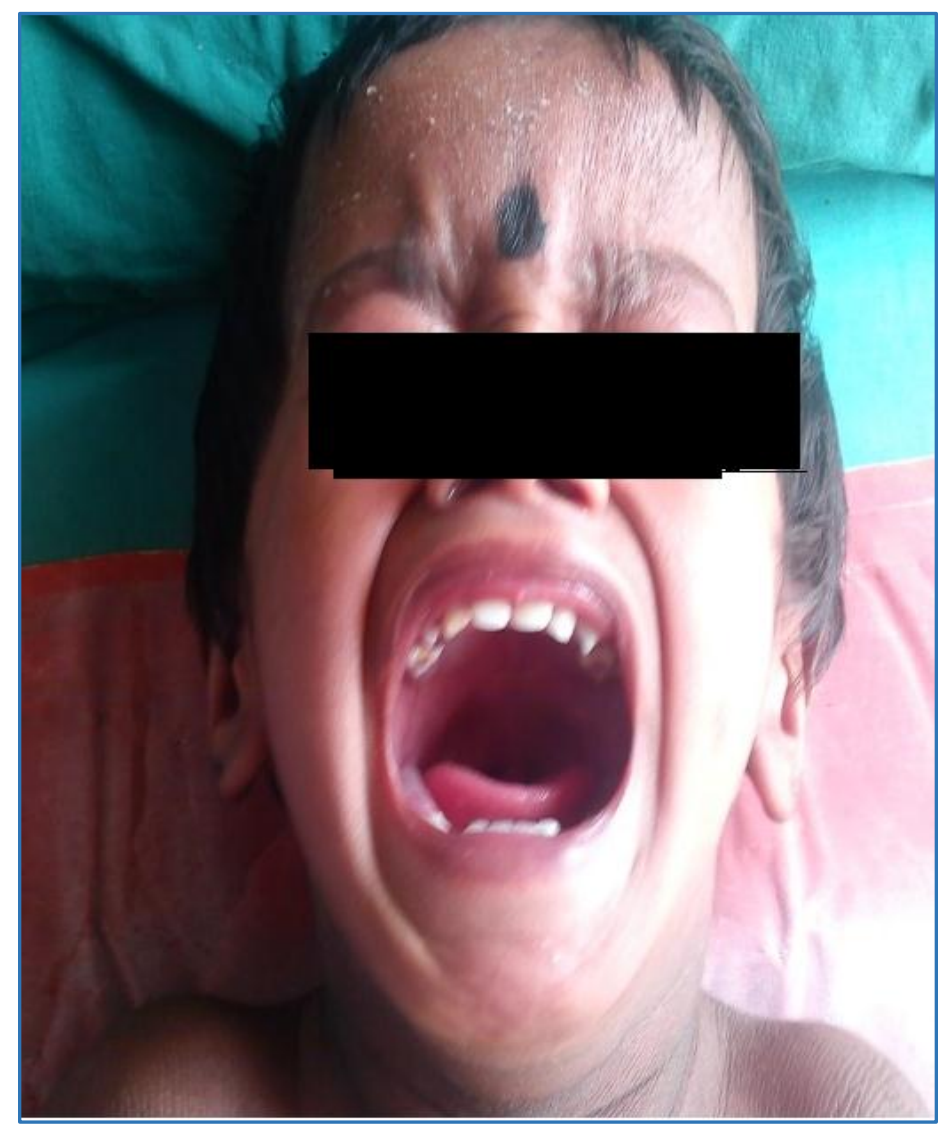

Figure 3. Ichthyosis over the Forehead and the Shoulder 


\begin{tabular}{|c|c|c|c|c|c|}
\hline Sl. No. & Age (Months) & Sex & Clinical Features & Imaging Findings & Diagnosis \\
\hline 1 & 37 & Male & $\begin{array}{c}\text { Port-wine stain in the right } \\
\text { upper face }\end{array}$ & $\begin{array}{l}\text { Leptomeningeal tumour in the } \\
\text { anterior part of falx cerebri }\end{array}$ & $\begin{array}{l}\text { Sturge-Weber } \\
\text { syndrome }\end{array}$ \\
\hline 2 & 15 & Male & Left hemifacial port-wine stain & $\begin{array}{l}\text { Leptomeningeal tumour over the } \\
\text { left frontal pole compressing the } \\
\text { same }\end{array}$ & $\begin{array}{l}\text { Sturge-Weber } \\
\text { syndrome }\end{array}$ \\
\hline 3 & 7 & Female & $\begin{array}{l}\text { Shagreen patch on the lower } \\
\text { spine }(5 * 3 \mathrm{~cm}) \text { at L3 level }\end{array}$ & $\begin{array}{l}\text { A cortical tuber in the right } \\
\text { parietal cortex }\end{array}$ & $\begin{array}{l}\text { Tuberous sclerosis } \\
\text { complex }\end{array}$ \\
\hline 4 & 68 & Male & $\begin{array}{c}\text { Adenoma sebaceum involving } \\
\text { the root of the nose to } \\
\text { nasolabial folds (Ash leaf } \\
\text { macule seen in father over } \\
\text { the right } \\
\text { infraorbital region) }\end{array}$ & $\begin{array}{l}\text { Multiple ependymal tumours in } \\
\text { both the lateral ventricles }\end{array}$ & Familial TSC \\
\hline 5 & 23 & Male & $\begin{array}{l}\text { Ash leaf macules on the left } \\
\text { hypochondrial region of the } \\
\text { abdomen and shagreen patch } \\
(2 * 3 \mathrm{~cm}) \text { in the left lumbar } \\
\text { region }\end{array}$ & $\begin{array}{l}\text { Multiple ependymal tumours in } \\
\text { the lateral ventricle }\end{array}$ & $\begin{array}{l}\text { Tuberous sclerosis } \\
\text { complex }\end{array}$ \\
\hline 6 & 9 & Male & $\begin{array}{c}\text { Generalised ichthyosis and } \\
\text { spastic paraplegia of lower limbs }\end{array}$ & $\begin{array}{c}\mathrm{T}_{2} \mathrm{~W} \text { axial MRI- bilateral } \\
\text { symmetrical hyperintense } \\
\text { lesions }\end{array}$ & $\begin{array}{l}\text { Sjogren-Larsson } \\
\text { syndrome }\end{array}$ \\
\hline 7 & 6 & Male & $\begin{array}{l}\text { Dark pigmented macule over the } \\
\text { left cheek }(3 * 3 \mathrm{~cm})\end{array}$ & $\begin{array}{l}\text { Circumscribed meningeal } \\
\text { tumour in the falx cerebri }\end{array}$ & Nevus of Ito \\
\hline
\end{tabular}

\section{DISCUSSION}

Sturge-Weber syndrome, Sjogren-Larsson syndrome and tuberous sclerosis complex were encountered in the study. Patients with TSC present mutations of the TSC1 and TSC2 genes, which intervene in cell cycle regulation. This is a dominant autosomal hereditary disease, though $60 \%-70 \%$ of all cases are the result of spontaneous mutations. ${ }^{[3]}$ The prevalence of TSC ranges from 1: 6,000 to 1: 10,000 individuals and the diagnosis is usually established between 4 - 10 years of age or in puberty. Tuberous sclerosis shows signs of being carriers of the gene TSC1 gene- located on chromosome 9q34, encodes protein called hamartin and TSC2 gene- located on chromosome 16p13 and encodes protein called tuberin for the disease when carefully examined. ${ }^{[4]}$ The most important neurological problems are mental retardation, seizures, autism and learning difficulties. Systemic manifestations include polycystic kidneys, honeycomb lung, retinal phakomatoses, rhabdomyomas, haemangiomas of liver/spleen and tubers in the basal ganglia. Sturge-Weber syndrome is a sporadic disease, but familial cases have been described..5] Port-wine stain generally represents progressive ectasia of superficial vascular plexus which stains pink in infancy, but becomes darker in the postnatal age.[6] It has an incidence of about 1: 50,000 live births. Sjogren-Larsson syndrome clinically manifests as ichthyosis at birth.[7] It presents with the clinical triad of ichthyosis, spastic paraplegia and intellectual delay. It is also associated with palmoplantar keratosis. It is inherited as an autosomal recessive fashion with mutation in the fatty aldehyde dehydrogenase enzyme (FADH3A2). It is diagnosed clinically or by culture of fibroblasts for fatty aldehyde dehydrogenase.[8]

\section{CONCLUSION}

Syndromic manifestation of NM can be efficiently screened with the external markers, which help in the diagnosis of the condition cost effectively.

\section{REFERENCES}

[1] Klar N, Cohen B, Lin DD. Neurocutaneous syndromes. Handb Clin Neurol 2016;135:565-89.

[2] Ruggieri M, Praticò AD. Mosaic neurocutaneous disorders and their causes. Semin Pediatr Neurol 2015;22(4):207-33.

[3] Comi AM. Sturge-Weber syndrome. Handb Clin Neurol 2015;132:157-68.

[4] Higueros E, Roe E, Granell E, et al. Sturge-Weber syndrome: a review. Actas Dermosifiliogr 2017;10(16):30442-2.

[5] Caban C, Khan N, Hasbani DM, et al. Genetics of tuberous sclerosis complex: implications for clinical practice. Appl Clin Genet 2016;10:1-8.

[6] Farrell CJ, Plotkin SR. Genetic causes of brain tumors: neurofibromatosis, tuberous sclerosis, von hippellindau, and other syndromes. Neurol Clin 2007;25(4):925-46.

[7] Dutra LA, Braga-Neto P, Pedroso JL, et al. SjogrenLarsson syndrome. Adv Exp Med Biol 2012;724:34450.

[8] Nagappa M, Bindu PS, Chiplunkar S, et al. Child neurology: sjögren-larsson syndrome. Neurology 2017;88(1):e1-4. 